\title{
The relationship between umbilical cord measurements and newborn outcomes
}

\author{
Cenk Soysal $^{1}$ (D) , Halil İbrahim Şişman ${ }^{1}$ (D) , İsmail Bıyık ${ }^{1}$ (D), Özlem Erten ${ }^{1}$ (D), \\ Burak Deliloğlu² iD), Damla Geçkalan Soysal² (iD), Nadi Keskin ${ }^{1}$ \\ ${ }^{1}$ Department of Obstetrics and Gynecology, School of Medicine, Kiitahya Health Sciences University, Kiitahya, Turkey \\ ${ }^{2}$ Department of Pediatrics, School of Medicine, Kiitahya Health Sciences University, Kiitahya, Turkey
}

\begin{abstract}
Objective: This study investigated the relationship between umbilical vein diameter and cord length and fetal outcome in low-risk pregnancies (fetuses appropriate for gestational age [AGA]).

Methods: A prospective cohort study of 39 singleton pregnant women aged 19-44 years at between $38+0$ and $41+6$ weeks of gestation was conducted. Case demographics, umbilical vein diameter measured by prenatal ultrasound, postnatal birth weight, gender, 1and 5-minute Apgar scores, blood gas analysis, and umbilical cord length were recorded. Fetuses with a fetal weight in the 10-90th percentile according to week of gestation were accepted as AGA.

Results: The mean age of the pregnant women was $27.5 \pm 5.3$ years. $33 \%(13 / 39)$ of the pregnant women were nulliparous. There was no statistically significant correlation between umbilical vein diameter and other variables in correlation analysis $(\mathrm{p}>0.050)$. Umbilical cord length and umbilical vein lactate level were found to have a statistically negative and significant correlation $(\mathrm{r}=-0.418 ; \mathrm{p}=0.015)$; however, no other pregnancy outcomes were found to have a significant correlation. There was no statistically significant difference between the median values of umbilical vein diameter and cord length by gender ( $\mathrm{p}=0.076$ and 0.181 , respectively).

Conclusion: In conclusion, this study found no relationship between umbilical vein diameter and cord length and fetal weight and pregnancy outcome in low-risk 38.0-41.6-week pregnancies (AGA fetuses). However, the obtained results still need to be confirmed by larger series.
\end{abstract}

Keywords: Umbilical vein diameter, umbilical cord length, umbilical vein, umbilical cord, fetal outcome.

\section{Introduction}

Factors affecting fetal development include genetics, fetal aneuploidy, maternal hypertension, diabetes mellitus, and placental factors. ${ }^{[1,2]}$ While the placenta supplies

\section{Özet: Umbilikal kord ve yenidoğan sonuçları arasındaki ilişki}

Amaç: Çalışmamızda, düşük riskli gebeliklerde (gestasyonel yaşa göre normal fetüsler [AGA]) umbilikal ven çapı ile kordon uzunluğu ve fetal sonuç arasındaki ilişkiyi araştırdık.

Yöntem: Gebeliğin 38+0 ve 41+6. haftaları arasında 19-44 yaşındaki 39 tekil gebelikten oluşan prospektif bir kohort çalışması gerçekleştirildi. Olguların demografik özellikleri, prenatal ultrason ile ölçülen umbilikal ven çapı, postnatal doğum ağırlığı, cinsiyet, 1 . ve 5. dakika Apgar skorları, kan gazı analizi ve umbilikal kord uzunluğu kaydedildi. Gestasyonel haftaya göre 10-90. persantilde olan fetal ağırlıklı fetüsler AGA kabul edildi.

Bulgular: Gebelerin ortalama yaşı $27.5 \pm 5.3$ idi. Gebelerin \%33'ì (13/39) nullipardı. Korelasyon analizinde umbilikal ven çapı ve diğer değişkenler arasında istatistiksel olarak anlamlı korelasyon yoktu $(\mathrm{p}>0.050)$. Umbilikal kord uzunluğu ve umbilikal ven laktat seviyesinin istatistiksel olarak negatif ve anlamlı korelasyona sahip olduğu bulundu ( $\mathrm{r}=-0.418 ; \mathrm{p}=0.015)$; ancak diğer gebelik sonuçlarında anlamlı korelasyon yoktu. Cinsiyete göre umbilikal ven çapı ve kordon uzunluğunun medyan değerleri arasında istatistiksel olarak anlamlı fark yoktu (sirasiyla $\mathrm{p}=0.076$ ve 0.181 ).

Sonuç: Sonuç olarak çalışmamızda, 38.0-41.6 haftalık gebeliklerde (AGA fetüslerde) umbilikal ven çapı ve kordon uzunluğu ile fetal ağırlık ve gebelik sonucu arasında bir ilişki bulamadık. Ancak elde edilen sonuçların yine de daha büyük seriler ile doğrulanmasi gerekmektedir.

Anahtar sözcükler: Umbilikal ven çapı, umbilikal kord uzunluğu, umbilikal ven, umbilikal kord, fetal sonuç.

the fetus with oxygen and nutrients, it transports carbon dioxide and waste products formed by the fetus into the maternal circulation. ${ }^{[3,4]}$ The umbilical cord is a helical link that is vital to the development of the fetus. When

Correspondence: Cenk Soysal, MD. Department of Obstetrics and Gynecology, School of Medicine, Kütahya Health Sciences University, Kütahya, Turkey. e-mail: drsoysalcenk@gmail.com / Received: September 24, 2021; Accepted: November 25, 2021

How to cite this article: Soysal C, Şişman Hİ, Bıyı İ, Erten Ö, Deliloğlu B, Geçkalan Soysal D, Keskin N. The relationship between umbilical cord measurements and newborn outcomes. Perinatal Journal 2021;29(3):225-230. doi:10.2399/prn.21.0293008 
the umbilical cord is sectioned, there are two arteries and a vein in the umbilical cord wrapped with Wharton's gel. The umbilical vein is the source of nourishment for the fetus, and studies show that fetal growth is delayed when blood flow in the umbilical vein is inadequate..$^{[5,6]}$

There are studies showing that umbilical vein diameter and umbilical cord diameter are associated with fetal weight. ${ }^{[7,8]}$ There are studies reporting the relationship between small umbilical cord diameter and adverse pregnancy outcomes in fetuses with fetal growth retardation. ${ }^{[9]}$ It has been noted that in the second trimester of pregnancy, pregnant women with thin umbilical cords have an increased likelihood of having fetal growth retardation. ${ }^{[9]}$ There are studies reporting that umbilical vein diameter measured in the third trimester does not help predict estimated fetal weight. ${ }^{[10]}$

The normal length of the umbilical cord is 50-60 $\mathrm{cm}^{[11]}$ Fetal growth retardation, congenital anomalies, intrapartum fetal distress, and an increased risk of fetal death are all associated with a short umbilical cord. ${ }^{[12]} \mathrm{A}$ long umbilical cord is associated with fetal risks, such as cord along its length, cord prolapse, cord knots, and intrapartum fetal distress. ${ }^{[11,13]}$

There is limited information on the relationship between umbilical vein diameter and cord length and fetal outcomes in low-risk pregnant women (fetuses appropriate for gestational age [AGA]). This study examined the relationship between umbilical vein diameter and cord length with fetal outcome in low-risk pregnancies (AGA fetuses).

\section{Methods}

This prospective cohort study was conducted at the Kütahya Health Sciences University Evliya Çelebi Training and Research Hospital between 01.07.2021 and 01.09.2021. Ethical approval was obtained from the Non-invasive Ethics Committee of Kütahya Health Sciences University, Kütahya, Turkey (Research number: 2021/11-08). The study was conducted with 39 singleton pregnant women aged between $38+0$ and $41+6$ weeks, 19-44 years. According to the week of gestation, a singleton pregnancy was determined to be AGA inclusion criteria. Fetuses with a fetal weight in the 10-90th percentile according to week of gestation were accepted as AGA. The week of gestation was determined by the last menstrual period, and early ultrasound measure- ments confirmed the week of gestation. Those with multiple pregnancies, pregnancy complications such as diabetes and hypertension, physical and chromosomal anomalies in their fetuses, fetal losses, intrauterine growth restriction, pre-term or post-term delivery, oligohydramnios, or polyhydramnios were excluded from the study. Case demographics, umbilical vein diameter measured by prenatal ultrasound, postnatal birth weight, gender, 1- and 5-minute Apgar scores, blood gas levels, and umbilical cord length were recorded.

The diameter of the umbilical vein was measured at the free part of the umbilical cord. During the measurements, the diameter of the umbilical vein (UV) was measured from the outside to the outside at the widest point of the umbilical cord (Fig. 1). The measurements were always performed by the same operator (CS). The measurements were performed three times. The average of these three measurements was taken. Measurements were performed using a Toshiba brand Aplio 400 model (Toshiba Medical Systems Corporation, Tochigi, Japan) and a $6.0-1.9 \mathrm{MHz} 4 \mathrm{D}$ probe. The measurements were performed in patients whose uterine contractions had not yet started. The umbilical cord was clamped after birth. It was cut into two parts. The total length of the umbilical cord was determined in $\mathrm{mm}$ by measuring the two ends with separate measuring tapes. After the placenta was removed, it was weighed, and its weight was noted in grams.

Statistical Package for the Social Sciences (version 25, SPSS Inc., Chicago, IL, USA) was used to analyze the

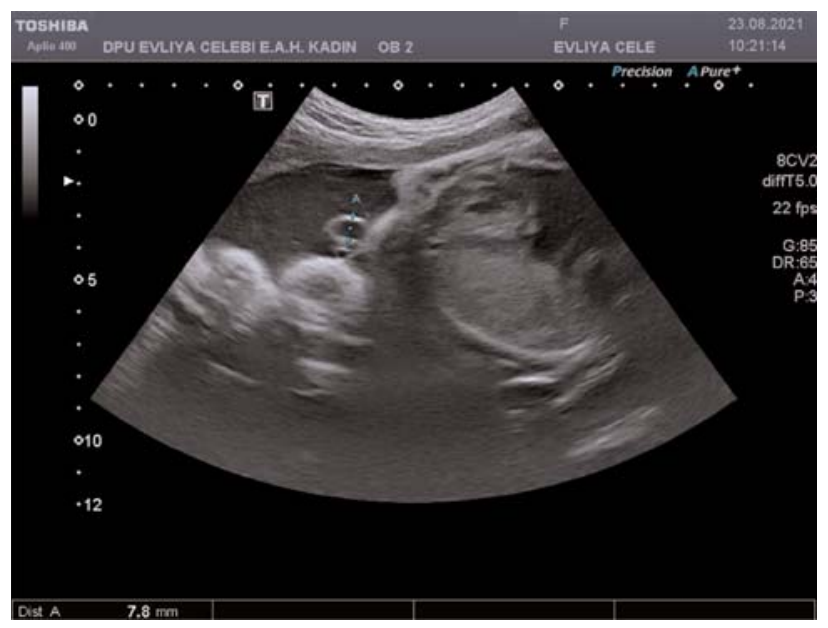

Fig. 1. Measurement of umbilical vein diameter by ultrasonography. 
data. Data are presented as mean \pm standard deviation and median [25th percentile; 75 th percentile]. Conformity to normal distribution was assessed using KolmogorovSmirnov test or Shapiro-Wilk test. Differences in continuous variables between groups were evaluated using Mann-Whitney $\mathrm{U}$ test. The relationships between categorical data and groups were analyzed using chi-square test. Correlations between variables were assessed using Spearman's correlation coefficient. A value of $\mathrm{p}<0.05$ was considered statistically significant.

\section{Results}

The mean age of the pregnant women was $27.5 \pm 5.3$ years. $33 \%(13 / 39)$ of the pregnant women were nulliparous. Table 1 shows the demographic data of the cases. There was no statistically significant correlation between umbilical vein diameter and other variables $(p>0.050)$ in correlation analysis. A statistically negative and moderate correlation was found between umbilical cord length and umbilical vein lactate level $(r=-0.418$; $\mathrm{p}=0.015)$. Table 2 shows the diameter of the umbilical vein and the length of the umbilical cord, as well as information on their correlation with pregnancy outcome. There was no statistically significant difference between the median values of umbilical vein diameter and cord length by gender (p-values: 0.076 and 0.181 , respectively) (Table 3).

\section{Discussion}

Many factors can affect the birth weight of the fetus. Umbilical vein parameters measured just before delivery may be important for both newborn weight and newborn outcomes. There was no statistically significant relationship identified between umbilical vein diameter and other variables in this study. There was a statistically negative and moderate relationship between umbilical cord length and umbilical vein lactate level, but no significant relationship was found with other pregnancy outcomes.

There are studies showing that the diameter of the umbilical cord and vein correlates with fetal weight. ${ }^{[8,10]}$ A thin umbilical cord has been shown to be associated with an increased risk of fetal distress in risky pregnancies (e.g., fetal growth retardation). However, no information on cord blood gas results has been reported. ${ }^{[9]}$ In their study examining the relationship of umbilical
Table 1. Demographic data of cohort.

\begin{tabular}{lc}
\hline Age (years) & $27.5 \pm 5.3$ \\
& $27.0[23.0 ; 32.0]$ \\
\hline BMI $\left(\mathrm{kg} / \mathrm{m}^{2}\right)$ & $29.1 \pm 5.6$ \\
& $28.6[26.1 ; 31.2]$ \\
\hline Gestational age (weeks) & $38.8 \pm 1.3$ \\
& $39.0[38.0 ; 40.0]$ \\
\hline Parity & $1.2 \pm 1.3$ \\
\hline Umbilical vein diameter $(\mathrm{mm})$ & $1.0[0.0 ; 2.0]$ \\
\hline Umbilical cord length (cm) & $8.9 \pm 6.5$ \\
& $7.6[6.1 ; 8.7]$ \\
\hline Placenta weight (g) & $53.4 \pm 7.2$ \\
& $52.0[50.0 ; 60.0]$ \\
\hline Apgar score (1-minute) & $621.5 \pm 129.0$ \\
& $632.0[540.0 ; 720.0]$ \\
\hline Apgar score (5-minute) & $8.4 \pm 1.3$ \\
& $9.0[9.0 ; 9.0]$ \\
\hline Birth weight (g) & $9.6 \pm 0.9$ \\
& $10.0[10.0 ; 10.0]$ \\
\hline Umbilical vein pH & $3122.5 \pm 515.6$ \\
& $3220.0[2850.0 ; 3450.0]$ \\
\hline pCO2 (mmHg) & $7.3 \pm 0.1$ \\
& $7.3[7.3 ; 7.3]$ \\
\hline Lactate (mmol/L) & $45.4 \pm 6.6$ \\
& $44.1[41.0 ; 48.0]$ \\
\hline Bicarbonate (mEq/L) & $2.7 \pm 1.6$ \\
\hline Base deficit (mmol/L) & $2.3[1.7 ; 3.6]$ \\
\hline & $22.2 \pm 1.6$ \\
& $22.1[21.2 ; 22.9]$ \\
\hline & $1.8 \pm 6.8$ \\
& $1.4 .2 ; 8.4]$ \\
\hline & \\
&
\end{tabular}

Values are presented as mean \pm standard deviation, median [interquartile range]. BMI: body mass index.

cord diameter with fetal development and fetal outcome in 652 pregnant women, Udoh et al. found that umbilical cord diameter showed a positive correlation with birth weight. They also showed that there was a poor fetal outcome in 50 pregnant women whose umbilical cord diameter was below the average in the first and second trimesters. ${ }^{[14]}$ Proctor et al. investigated the relationship between umbilical cord diameter and fetal weight in 497 pregnant women at 18-41 weeks of gestation. They showed a positive correlation of umbilical cord diameter with birth weight and placental weight. ${ }^{[15]}$ Ghezzi et al. found that the total area of the umbilical cord and umbilical veins were small in neonates with fetal growth restriction who admitted to the neonatal intensive care unit. They also found that a small umbilical vein area was associated with adverse neonatal outcomes. ${ }^{[7]}$ In the study by Rigano et al., it 
Table 2. Investigation of the relationship between umbilical vein diameter and umbilical cord length and birth results.

\begin{tabular}{|c|c|c|c|}
\hline & & Umbilical vein diameter & Umbilical cord length \\
\hline \multirow[t]{2}{*}{ Age } & $r$ & 0.283 & -0.055 \\
\hline & $p$ & 0.081 & 0.737 \\
\hline \multirow[t]{2}{*}{ BMI } & $r$ & 0.187 & -0.028 \\
\hline & $p$ & 0.253 & 0.865 \\
\hline \multirow[t]{2}{*}{ Gestational age } & $r$ & -0.225 & 0.236 \\
\hline & $p$ & 0.168 & 0.147 \\
\hline \multirow[t]{2}{*}{ Parity } & $r$ & 0.143 & -0.053 \\
\hline & $\mathrm{p}$ & 0.385 & 0.751 \\
\hline \multirow[t]{2}{*}{ Apgar scores (1-minute) } & r & -0.307 & 0.307 \\
\hline & $\mathrm{p}$ & 0.057 & 0.057 \\
\hline \multirow[t]{2}{*}{ Apgar scores (5-minute) } & r & -0.339 & 0.297 \\
\hline & $p$ & 0.035 & 0.066 \\
\hline \multirow[t]{2}{*}{ Birth weight } & $r$ & -0.119 & 0.329 \\
\hline & $p$ & 0.470 & 0.041 \\
\hline \multirow[t]{2}{*}{$\mathrm{pH}$} & r & -0.172 & -0.003 \\
\hline & $\mathrm{p}$ & 0.314 & 0.984 \\
\hline \multirow[t]{2}{*}{$\mathrm{PCO}_{2}$} & r & 0.059 & 0.040 \\
\hline & $p$ & 0.732 & 0.816 \\
\hline \multirow[t]{2}{*}{ Lactate } & $r$ & 0.343 & -0.418 \\
\hline & $\mathrm{p}$ & 0.050 & 0.015 \\
\hline \multirow[t]{2}{*}{ Bicarbonate } & r & 0.069 & 0.102 \\
\hline & $\mathrm{p}$ & 0.701 & 0.574 \\
\hline \multirow[t]{2}{*}{ Base deficit } & r & 0.112 & -0.211 \\
\hline & $p$ & 0.535 & 0.239 \\
\hline \multirow[t]{2}{*}{ Placenta weight } & $r$ & 0.256 & -0.210 \\
\hline & $p$ & 0.115 & 0.199 \\
\hline
\end{tabular}

BMI: Body mass index; r: Spearman's rho correlation coefficient.

was shown that there is a correlation between the decrease in umbilical vein diameter in fetuses with growth retardation. ${ }^{[13]}$ The relationship between umbilical cord or umbilical vein diameter and pregnancy outcomes in low-risk pregnant women has not yet been clarified. There was no statistically significant relationship identified between umbilical vein diameter and other variables in this study.

Tutus et al. found that umbilical vein diameter and fetal birth were inversely related in newborns with LGA.
As the umbilical vein diameter decreases in these 20-24 weeks, the estimated fetal birth weight increases. ${ }^{[16]}$

Köşüş et al. examined ultrasonographic umbilical artery and umbilical vein diameters of 720 low-risk pregnant women between 20th and 40th weeks of gestation. Moreover, they compared these measurements to the fetal biometry and predicted fetal weights. They found a strong correlation between umbilical vein diameters and predicted fetal weights until 34 weeks. They found that the umbilical vein measurement measured

Table 3. Comparison of umbilical vein diameter and umbilical cord length values by gender.

\begin{tabular}{lcrr} 
& & \multicolumn{2}{c}{ Gender } \\
\cline { 3 - 4 } Umbilical vein diameter & Notation & Female & Male \\
& Avg \pm std. deviation & $8.5 \pm 7$ & $9.3 \pm 6.3$ \\
Umbilical cord length & Avg (min.-max.) & $6.8(5.2-37)$ & $7.9(5.7-35)$ \\
& Avg \pm std. deviation & $53.4 \pm 11.7$ & $49.9 \pm 11.6$ \\
\hline
\end{tabular}


after 34 weeks did not affect the estimated fetal weight. However, they stated that there was no relationship between umbilical vein/artery rate and predicted fetal weight, and gestational age. ${ }^{[6]}$ In the study by Predanic and Perni, it was seen that the umbilical cord thickness measured in the second trimester was not correlated with neonatal birth weight. ${ }^{[17]}$

Köşüş et al. found that the UV/UA ratio measured below 34 weeks of gestation helps determine the estimated fetal weight, but it has no utility in prediction after 34 weeks of gestation. ${ }^{[6]}$ Rostamzadeh et al. reported that umbilical cord and vein diameter assessed after 30 weeks of gestation was not associated with fetal weight. ${ }^{[18]}$ In their study, Togni et al. found no relationship between umbilical cord thickness and fetal weight measured after 33 weeks of gestation. ${ }^{[19]}$ Our study showed no relationship between umbilical vein diameter and neonatal weight and neonatal outcomes (blood gas values, etc.) in low-risk pregnancies at 38.0-41.6 weeks of gestation.

Short and long cord lengths have been reported to be associated with adverse pregnancy outcomes. ${ }^{[11-13]} \mathrm{A}$ long umbilical cord is considered as more than $100 \mathrm{~cm}$ long, whereas a short umbilical cord is regarded as less than 30 mm long. ${ }^{[11]}$ In this study, no case was found to have a short or long umbilical cord. There was a statistically negative and moderate relationship between umbilical cord length and umbilical vein lactate level, but no significant association was found with other pregnancy outcomes.

\section{Strengths and limitations}

To our knowledge, this is the first study in the literature to examine the relationship between umbilical vein diameter and cord length and fetal outcome in low-risk pregnant women. This is the strength of our study. The limited number of cases can be considered a limitation of our study.

\section{Conclusion}

In conclusion, this study found that umbilical vein diameter and cord length were not associated with fetal weight and pregnancy outcomes in 38.0-41.6 weeks of low-risk pregnancies (AGA fetuses). However, the obtained results still need to be confirmed by larger series.
Funding: This work did not receive any specific grant from funding agencies in the public, commercial, or not-for-profit sectors.

Compliance with Ethical Standards: The authors stated that the standards regarding research and publication ethics, the Personal Data Protection Law and the copyright regulations applicable to intellectual and artistic works are complied with and there is no conflict of interest.

\section{References}

1. Howell KR, Powell TL. Effects of maternal obesity on placental function and fetal development. Reproduction 2017;153: R97-R108. [PubMed] [CrossRef]

2. Wright C, Sibley CP. Placental transfer in health and disease. In Kay H, Nelson M, Yuping W, editors. The placenta: from development to disease. Hoboken, NJ: John Wiley and Sons.; 2011. p. 66-74.

3. Perazzolo S, Hirschmugl B, Wadsack C, Desoye G, Lewis RM, Sengers BG. The influence of placental metabolism on fatty acid transfer to the fetus. J Lipid Res 2017;58:443-54. [PubMed] [CrossRef]

4. Boito S, Struijk PC, Ursem NTC, Stijnen T, Wladimiroff JW. Umbilical venous volume flow in the normally developing and growth-restricted human fetus. Ultrasound Obstet Gynecol 2002;19:344-9. [PubMed] [CrossRef]

5. Baschat AA, Gembruch U, Reiss I, Weiner CP, Harman CR. Relationship between arterial and venous Doppler and perinatal outcome in fetal growth restriction. Ultrasound Obstet Gynecol 2000;16:407-13. [PubMed] [CrossRef]

6. Köşüş A, Köşüş N, Turhan NÖ. Is there any relation between umbilical artery and vein diameter and estimated fetal weight in healthy pregnant women? J Med Ultrason (2001) 2012;39: 227-34. [PubMed] [CrossRef]

7. Ghezzi F, Raio L, Günter Duwe D, Cromi A, Karousou E, Dürig P. Sonographic umbilical vessel morphometry and perinatal outcome of fetuses with a lean umbilical cord. J Clin Ultrasound 2005;33:18-23. [PubMed] [CrossRef]

8. Raio L, Ghezzi F, Di Naro E, Franchi M, Maymon, E, Mueller $\mathrm{MD}$, et al. Prenatal diagnosis of a lean umbilical cord: a simple marker for the fetus at risk of being small for gestational age at birth. Ultrasound Obstet Gynecol 1999;13:176-80. [PubMed] [CrossRef]

9. Barbieri C, Cecatti JG, Krupa F, Marussi EF, Costa JV. Validation study of the capacity of the reference curves of ultrasonographic measurements of the umbilical cord to identify deviations in estimated fetal weight. Acta Obstet Gynecol Scand 2008;87:286-91. [PubMed] [CrossRef]

10. Balkawade NU, Shinde MA. Study of length of umbilical cord and fetal outcome: a study of 1,000 deliveries. J Obstet Gynaecol India 2012;62:520-5. [PubMed] [CrossRef]

11. Krakowiak P, Smith EN, de Bruyn G, Lydon-Rochelle MT. Risk factors and outcomes associated with a short umbilical cord. Obstet Gynecol 2004;103:119-27. [PubMed] [CrossRef] 
12. Spellacy WN, Gravem H, Fisch RO. The umbilical cord complications of true knots, nuchal coils and cords around the body. Report from the collaborative study of cerebral palsy. Am J Obstet Gynaecol 1966;94:1136-42. [PubMed] [CrossRef]

13. Rigano S, Bozzo M, Padoan A, Mustoni P, Bellotti M, Galan HL, et al. Small size-specific umbilical vein diameter in severe growth restricted fetuses that die in utero. Prenat Diagn 2008; 28:908-13. [PubMed] [CrossRef]

14. Udoh BE, Erim A, Anthony E. Sonographic assessment of umbilical cord diameter as an indicator of fetal growth and perinatal outcome. Journal of Diagnostic Medical Sonography 2021;37:41-5. [CrossRef]

15. Proctor LK, Fitzgerald B, Whittle WL, Mokhtari N, Lee E, Machin G, Kingdom JC, Keating SJ. Umbilical cord diameter percentile curves and their correlation to birth weight and placental pathology. Placenta 2013;34:62-6. [PubMed] [CrossRef]
16. Tutus S, Asal N, Uysal G, Şahin H. Is there a relationship between high birth weight and umbilical vein diameter? J Matern Fetal Neonatal Med 2021;34:3609-3613. [PubMed] [CrossRef]

17. Predanic M, Perni SC. Absence of a relationship between umbilical cord thickness and coiling patterns. J Ultrasound Med 2005;24:1491-6. [PubMed] [CrossRef]

18. Rostamzadeh S, Kalantari M, Shahriari M, Shakiba M. Sonographic measurement of the umbilical cord and its vessels and their relation with fetal anthropometric measurements. Iran J Radiol 2015;22;12:e12230. [PubMed] [CrossRef]

19. Togni FA, Araujo Júnior E, Vasques FAP, Moron AF, Torloni MR, Nardozza LMM. The cross-sectional area of umbilical cord components in normal pregnancy. Int J Gynaecol Obstet 2007;96:156-61. [PubMed] [CrossRef]

This work is licensed under the Creative Commons Attribution-NonCommercial-NoDerivs 4.0 Unported (CC BY-NC-ND4.0) License. To view a copy of this license, visit http://creativecommons.org/licenses/by-nc-nd/4.0/ or send a letter to Creative Commons, PO Box 1866, Mountain View, CA 94042, USA.

Publisher's Note: The content of this publication does not necessarily reflect the views or policies of the publisher, nor does any mention of trade names, commercial products, or organizations imply endorsement by the publisher. Scientific and legal responsibilities of published manuscript belong to their author(s). The publisher remains neutral with regard to jurisdictional claims in published maps and institutional affiliations. 